\title{
Tumor suppressor berberine binds VASP to inhibit cell migration in basal-like breast cancer
}

\author{
Ke Su${ }^{1, *}$, Pengchao $\mathrm{Hu}^{2, *}$, Xiaolan Wang ${ }^{3}$, Changchun Kuang ${ }^{4}$, Qingmin Xiang ${ }^{2}$, \\ Fang Yang ${ }^{5}$, Jin Xiang ${ }^{6}$, Shan $\mathrm{Zhu}^{7}$, Lei $\mathrm{Wei}^{2}$, Jingwei Zhang ${ }^{8}$ \\ ${ }^{1}$ Department of Nephrology, Renmin Hospital of Wuhan University, Wuhan 430060, P. R. China \\ ${ }^{2}$ Department of Pathophysiology, School of Medicine, Wuhan University, Wuhan 430071, P. R. China \\ ${ }^{3}$ Department of Pathology, Shanghai First People's Hospital, Shanghai 200080, P. R. China \\ ${ }^{4}$ Department of Pharmacy, Wuhan General Hospital of Guangzhou Command, Wuhan 430070, P. R. China \\ ${ }^{5}$ Department of Plant Science, College of Life Sciences, Wuhan University, Wuhan 430072, P. R. China \\ ${ }^{6}$ Department of Pharmacology, College of Pharmacy, Wuhan University, Wuhan 430071, P. R. China \\ ${ }^{7}$ Department of Breast and Thyroid Surgery, Renmin Hospital of Wuhan University, Wuhan 430060, P. R. China \\ ${ }^{8}$ Department of Oncology, Zhongnan Hospital of Wuhan University, Wuhan 430071, P. R. China \\ *These authors have contributed equally to this work
}

Correspondence to: Jingwei Zhang, email: zjwzhang68@hotmail.com

Keywords: berberine, basal-like subtype breast cancer, VASP, polymerization

Received: October 23, $2015 \quad$ Accepted: May 29, 2016

Published: June 13, 2016

\section{ABSTRACT}

Berberine is a plant-derived compound used in traditional Chinese medicine, which has been shown to inhibit cell proliferation and migration in breast cancer. On the other hand, vasodilator-stimulated phosphoprotein (VASP) promotes actin filament elongation and cell migration. We previously showed that VASP is overexpressed in high-motility breast cancer cells. Here we investigated whether the anti-tumorigenic effects of berberine are mediated by binding VASP in basal-like breast cancer. Our results show that berberine suppresses proliferation and migration of MDA-MB-231 cells as well as tumor growth in MDA-MB-231 nude mouse xenografts. We also show that berberine binds to VASP, inducing changes in its secondary structure and inhibits actin polymerization. Our study reveals the mechanism underlying berberine's inhibition of cell proliferation and migration in basal-like breast cancer, highlighting the use of berberine as a potential adjuvant therapeutic agent.

\section{INTRODUCTION}

Breast cancer is the most common malignancy in women worldwide and its mortality rate is second to cervical cancer in developing countries [1]. Over the past 30 years, the incidence and mortality of breast cancer have been increasing, with a rate that is second only to lung cancer [1]. The incidence of breast cancer in China is relatively low compared to that in other countries, but soared from 30,000 cases per year in the late 1980 s to 67,000 in the early 1990 s [2].

Gene expression profiling has allowed to classify breast cancer into four subtypes [3]: luminal A (ER- and/or PR-positive, HER-2-negative, Ki-67 expression less than 14\%), luminal B (ER- and/or PR-positive, HER-2negative, Ki-67 expression more than or equal to $14 \%$; or ER- and/or PR-positive, HER-2 overexpression, Ki-67 at any level), basal-like (ER- and PR-negative, HER-2-negative), and HER-2 overexpression (ER- and PR-negative, HER-2 overexpression). Luminal A is the most common type of cancer ( $\sim 6 \%$ of cases), followed by basal-like $(\sim 28.8 \%)$, luminal B $(\sim 14.7 \%)$ and HER2 overexpression $(\sim 10.4 \%)[4,5]$. These four molecular subtypes of breast cancer differ in phenotype, response to drugs, and survival rates, thus requiring different treatments. Basal-like breast cancer is characterized by larger, high-grade tumors, with higher risk of lymph node and distant metastasis than the other subtypes [4, 6-8]. While the luminal and HER-2 overexpression types of breast cancer are responsive to targeted treatments, systemic chemotherapy is still the main form of routine 
treatment for basal-like breast cancer [9], which is characterized by poor prognosis [10].

The alkaloid berberine (berberine, BBR) can be extracted from multiple plants and has been long used as a non-prescription drug to treat diarrhea. In addition, pharmacological and clinical studies have demonstrated other beneficial effects from berberine treatment [11], including inhibition of tumor growth in a variety of cancer types [12-15]. In addition, berberine can inhibit invasion and metastasis of breast cancer MCF-7 (luminal A type) and MDA-MB-231 cells (basal-like type) [16-18].

Previously, our group showed that the actinassociated protein vasodilator-stimulated phosphoprotein (VASP) promotes cell proliferation, adhesion, motility and cell migration $[19,20]$, and is overexpressed in highmotility breast cancer cells, that is to say, VASP expression was higher in MDA-MB-231 cell than that in MCF-7 cell [17]. Furthermore, knocking down VASP expression in breast cancer cells inhibits cell migration and invasion [17]. Thus, inhibition of cytoskeletal rearrangements by targeting VASP-induced actin assembly could have therapeutic benefits in basal-like breast cancer.

In this study, we evaluated the effects of berberine treatment on MDA-MB-231 and MCF-7 breast cancer cells in vitro and in vivo. We found that berberine binds to VASP and inhibits actin filament elongation, especially in basal-like breast cancer cells.

\section{RESULTS}

\section{Expression of VASP in different breast cancer subtypes}

First, we performed immunohistochemical analysis of VASP in 41 breast cancer samples. Among the different subtypes, strong expression $(+++)$ of VASP was present in $25.0 \%$ (2/8) of Luminal A, 10.5\% (2/19) of luminal B, 71.4\% (5/7) of basal-like, and 71.4\% (5/7) of HER-2 overexpression samples (Table 1). As expected, cells positive for ER/PR showed a typical nuclear staining pattern (data not shown), whereas HER-2-positive tissues were characterized by a membrane pattern (data not shown). Immunostaining against VASP showed a ubiquitous expression pattern in most epithelial cells and a cytosolic as well as focal pattern in tumors (Figure 1). In addition, patients with basal-like and HER-2-positive subtypes exhibited particularly high VASP expression. Therefore, our data suggests that high expression of VASP correlates with basal-like breast cancer (luminal A or B vs. basal-like, $\mathrm{P}<0.05$ ) (Table 1).

\section{Berberine inhibits the proliferation of MDA- MB-231 and MCF-7 cells differentially}

To compare the effects of berberine on the proliferation of basal-like and luminal-type breast cancer cells, MCF-7 (luminal A phenotype) and MDA-
MB-231 cells (basal-like phenotype) were treated with different concentrations of berberine, and cell viability was analyzed by MTT assay. MDA-MB-231 cells showed reduced proliferation (76.01\% vs. $29.85 \%$ without and with treatment, respectively) (Figure 2A). Conversely, MCF-7 cells treated with berberine exhibited a much milder reduction in proliferation (from $93.40 \%$ to $56.45 \%$ ) (Figure $2 \mathrm{~B}$ ). Therefore, our data show that berberine inhibits MDA-MB-231 and MCF-7 cell proliferation, and that this effect is stronger in MDAMB-231 cells.

\section{Berberine inhibits the migration of MDA-MB-231 and MCF-7 cells differentially}

To evaluate berberine's inhibitory effect on breast cancer cell migration, we conducted transwell migration assays. Our results show that administration of berberine decreases migration of both MDA-MB-231 and MCF-7 cells in a dosage- and time-dependent manner (Figure $3 \mathrm{~A}$ and $3 \mathrm{~B}$ ). After $36 \mathrm{~h}$ of berberine treatment, the reduction in migration ability of MDA-MB-231 cells ranged between $30 \%$ at lower concentration $(0.1 \mu \mathrm{M})$ and $99 \%$ at higher concentration $(50 \mu \mathrm{M})$. The reduction in migration of MCF-7 cells ranged between $30 \%$ at $0.1 \mu \mathrm{M}$ berberine and $84 \%$ at $50 \mu \mathrm{M}$ berberine (Figure 3C and 3D). Similarly, after $48 \mathrm{~h}$ of treatment the reduction in cell migration was between $23 \%(0.1 \mu \mathrm{M})$ and $95 \%(50 \mu \mathrm{M})$ in MDA-MB-231 cells and between $5 \%(0.1 \mu \mathrm{M})$ and $82 \%$ $(50 \mu \mathrm{M})$ in MCF-7 cells (Figure $3 \mathrm{C}$ and $3 \mathrm{D}$ ). Therefore, berberine suppresses migration of MDA-MB-231 cells more efficiently than migration of MCF-7 cells (Figure $3 \mathrm{C}$ and $3 \mathrm{D}$ ). It should be noted that the basal number of invading MCF-7 cells was much lower than that of MDAMB-231 cells, implying that the latter possess higher migration ability and are therefore more vulnerable to the anti-migration effect of berberine.

\section{Berberine inhibits basal-like subtype breast cancer growth in a xenograft mouse model}

To examine the effect of berberine on breast cancer growth in vivo, we subcutaneously injected MDA-MB-231 cells into 6 weeks old BALB/ $\mathrm{c}^{\mathrm{nu} / \mathrm{nu}}$ athymic mice. When tumor volume reached 80 to $200 \mathrm{~mm}^{3}$, the mice were divided into three groups and treated with intraperitoneal injections of placebo, berberine $(10 \mathrm{mg} / \mathrm{kg})$ or doxorubicin $(4 \mathrm{mg} /$ $\mathrm{kg}$ ) every four days (Figure 4A). Doxorubicin is the most effective chemotherapy drug for breast cancer treatment; therefore, we used it here as a positive control. Our results show that berberine or doxorubicin did not alter body weight (Figure 4B), and had no effects on the survival of tumor-bearing mice (Figure 4C). However, mice injected with berberine showed decreased tumor volume and reduced tumor weight 
Table 1: Immunohistochemistry analysis of VASP expression in four subtypes of breast cancer

\begin{tabular}{lcccccccc}
\hline & Cases (n) & \multicolumn{3}{c}{ VASP } & & \multicolumn{3}{c}{ VASP (n\%) } \\
\cline { 3 - 5 } \cline { 7 - 9 } & & + & ++ & +++ & & + & ++ & +++ \\
\hline Luminal A & 8 & 3 & 3 & 2 & & 37.5 & 37.5 & 25.0 \\
Luminal B & 19 & 9 & 8 & 2 & & 47.4 & 42.1 & 10.5 \\
Basal-like & 7 & 1 & 1 & 5 & & 14.3 & 14.3 & 71.4 \\
HER-2 & 7 & 0 & 2 & 5 & & 0 & 28.6 & 71.4 \\
\hline
\end{tabular}

$\mathrm{n}$ : indicates the sample numbers in that category used for immunohistochemistry staining.

,+++ and +++ : indicate weak, moderate, or strong staining intensity, respectively.

$(\mathrm{n} \%)$ represent the percentage of samples with varying degrees positive staining in cytoplasm.

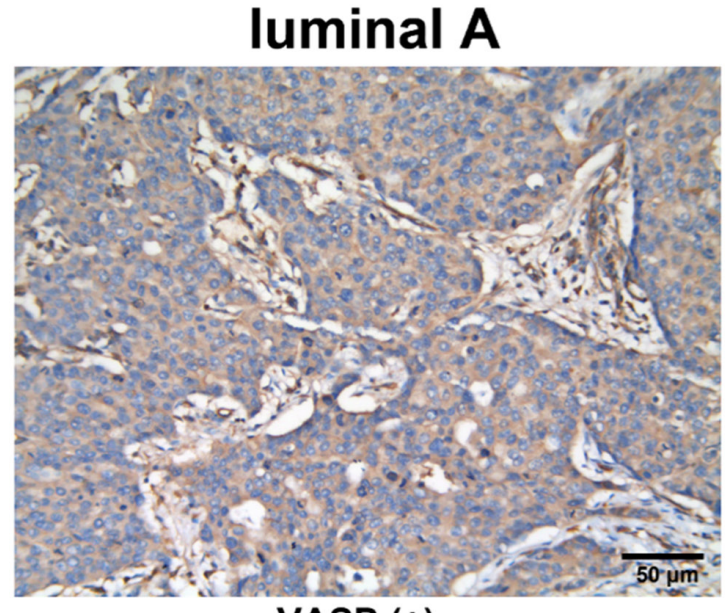

$\operatorname{VASP}(+)$

basal-like

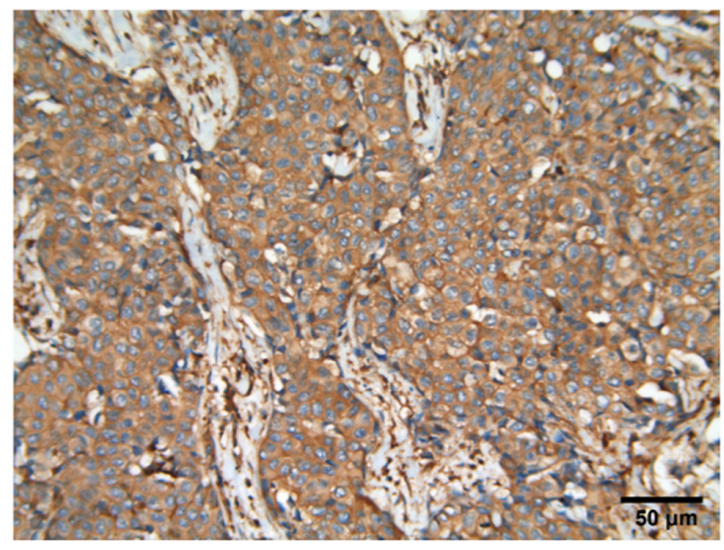

VASP (+++)

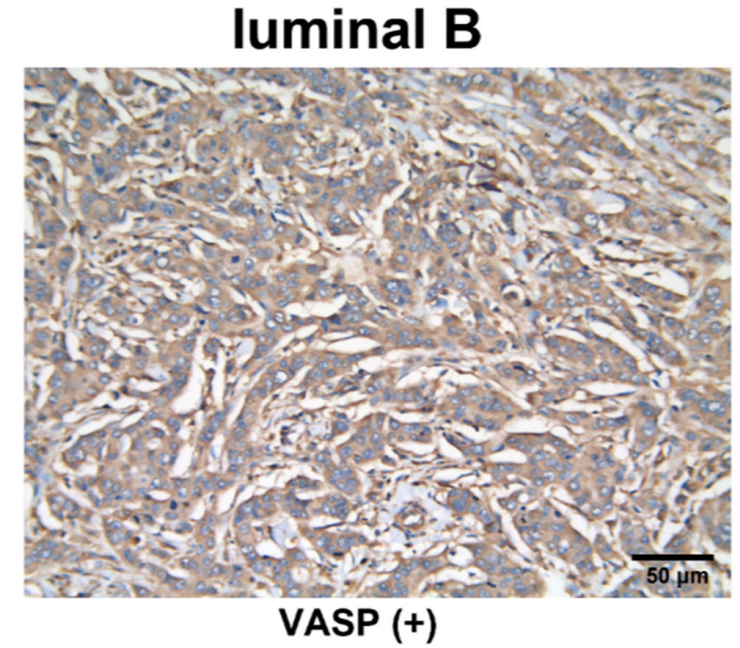

HER2 overexpressing

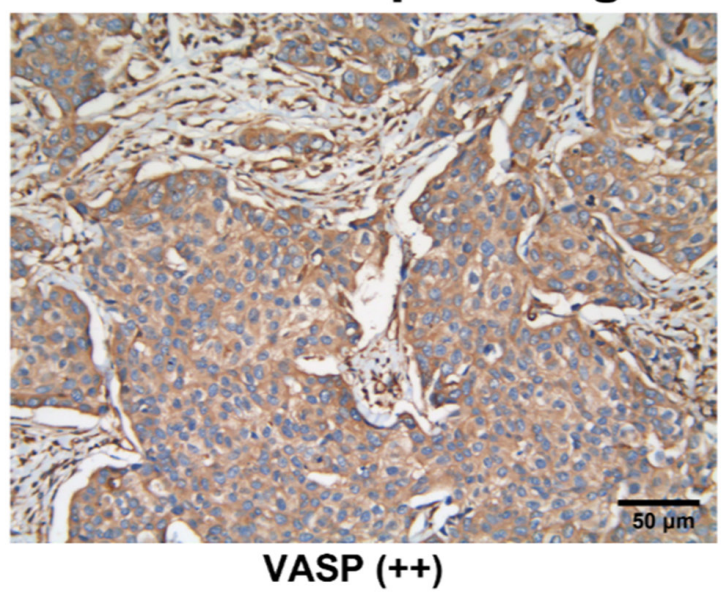

Figure 1: VASP expression in four subtypes of breast cancer. Immunohistochemical analysis of VASP in different subtypes of breast cancer. luminal A: weakly positive $(+)$; luminal B: weakly positive $(+)$; basal-like: strongly positive $(+++)$; HER-2 overexpression: moderately positive $(++)$. $(200 \times$ magnification $)$.

compared to the control, similarly to doxorubicin (Figure 4D-4G). In particular, the treated tumors displayed a substantial growth delay of 12 days (P $<0.05$ ) compared to controls (Figure 4F). Although doxorubicin showed stronger inhibition of tumor growth than berberine, our results indicate that berberine suppresses the growth of basal-like subtype breast cancer cells ex vivo. 
A

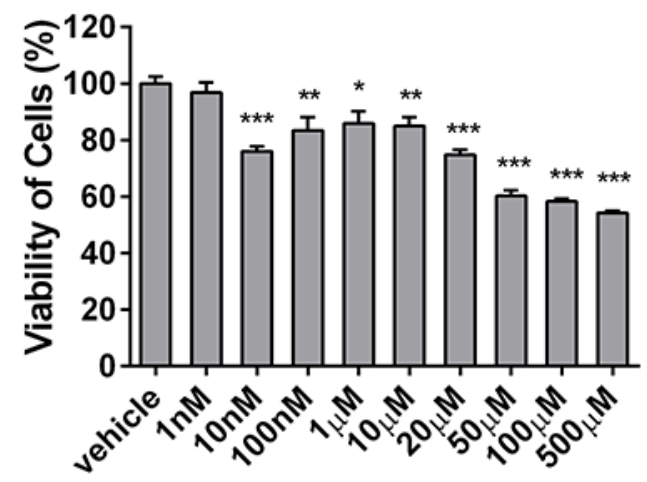

MDA-MB-231
B

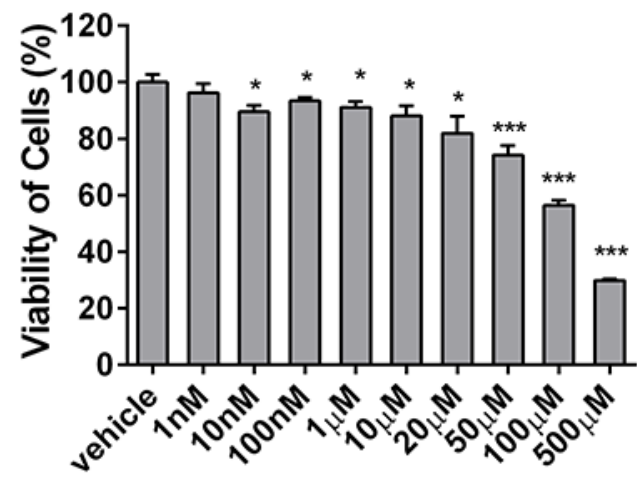

MCF-7

Figure 2: Berberine inhibits the proliferation of MDA-MB-231 and MCF-7 cells. MDA-MB-231 and MCF-7 cells were treated with berberine dissolved in DMSO or DMSO as a vehicle control for $24 \mathrm{~h}$. A. The viability of MDA-MB-231 cells was determined by MTT assay. B. The viability of MCF-7 cells was determined by MTT assay. Each experiment was repeated three times. ${ }^{*} \mathrm{P}<0.05$, $* * \mathrm{P}<0.01, * * * \mathrm{P}<0.001$

A

A MDA-MB-231

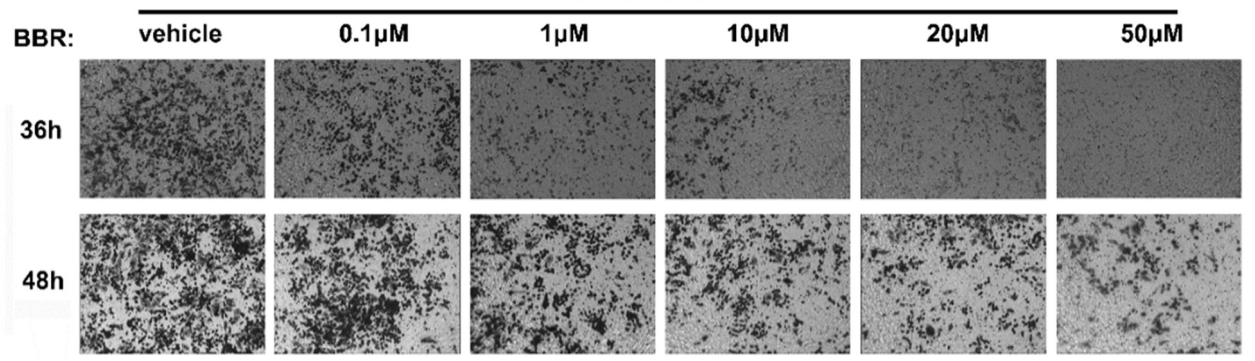

B

MCF-7
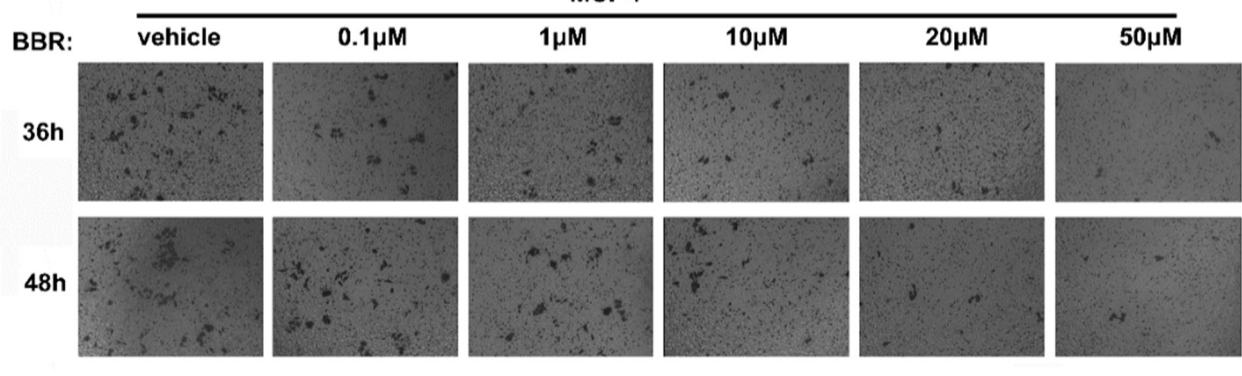

C

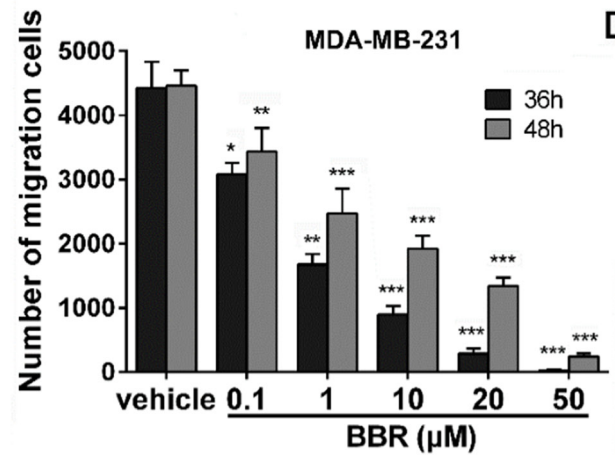

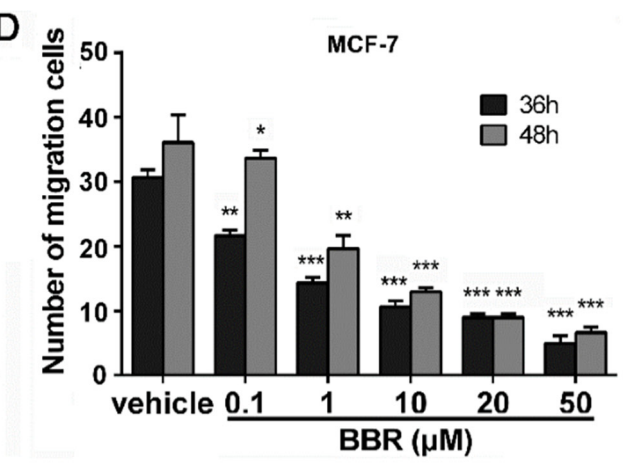

Figure 3: Berberine inhibits the migration of MDA-MB-231 and MCF-7 cells. A. The migration ability of MDA-MB-231 cells was measured using transwell assay. B. The migration ability of MCF-7 cells was measured using transwell assay. C. Number of MDAMB-231 cells migrating through the membrane. D. Number of MCF-7 cells migrating through the membrane. Data were expressed as mean \pm standard error of the mean from three independent experiments. ${ }^{*} \mathrm{P}<0.05,{ }^{*} \mathrm{P}<0.01,{ }^{*} * \mathrm{P}<0.001, v s$. vehicle control. 

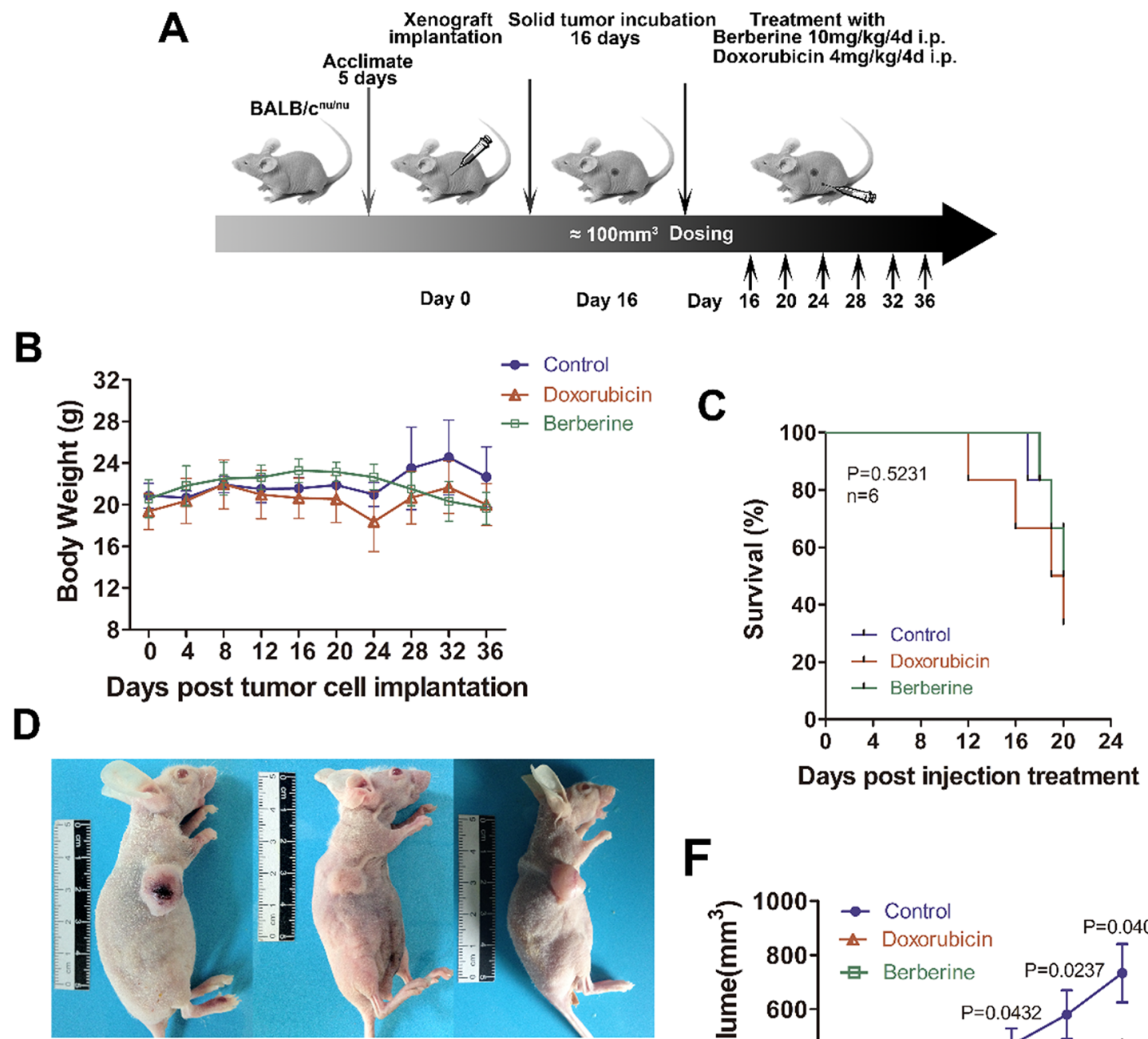

$\mathbf{F}$
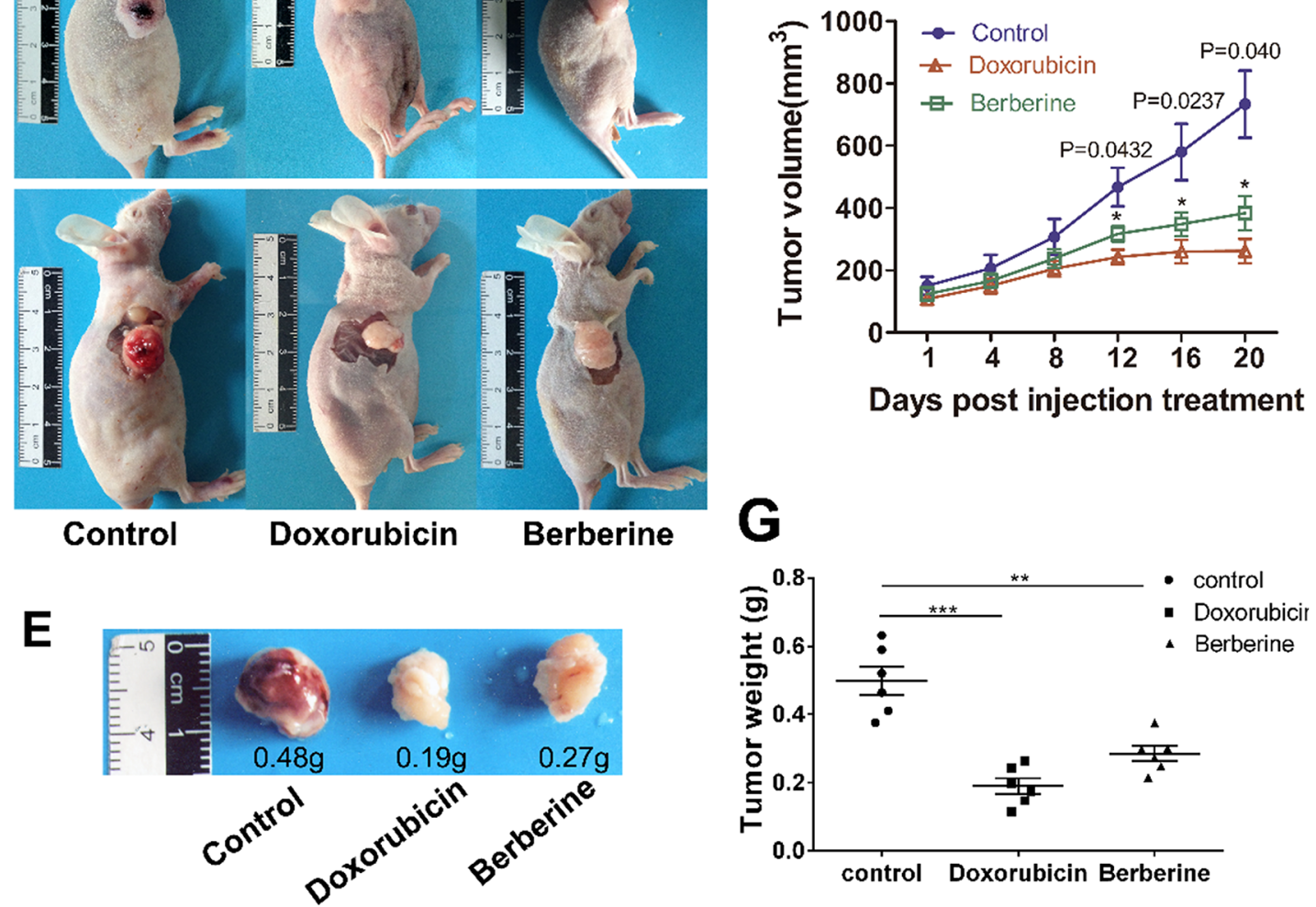

Figure 4: Berberine inhibits tumor growth in the MDA-MB-231 xenograft model. A. Experimental design of xenograft animal model. B. Body weight of xenografted mice. C. Kaplan-Meier survival analysis and log-rank test survival of xenografted mice (P $>$ 0.05 ,). D. Representative images of mice with solid tumors. E. Representative tumor growth and weight of xenografted mice. F. Volumes of tumors from xenografted mice. Data are presented as mean \pm standard error of the mean at day 10-36 post-tumor implantation. $* \mathrm{P}<0.05$. G. Weights of solid tumors extracted from sacrificed mice. $* * * \mathrm{P}<0.001$ and $* * \mathrm{P}<0.01$. 


\section{Berberine has no effects on transcription and expression of VASP}

Given VASP's role in breast cancer cell motility and berberine's inhibition of cell motility, we tested whether VASP is regulated by berberine. We first measured VASP expression in MDA-MB-231 and MCF-7 cells $48 \mathrm{~h}$ after treatment with different concentrations of berberine. Our results show that VASP expression at both the protein (Figure 5A) and the mRNA level (Figure 5B) in either cell line is unaffected by berberine treatment.

\section{Berberine binds to VASP}

To investigate whether berberine binds to the VASP protein, the fluorescence emission spectra of the tryptophan residues in VASP were recorded following excitation at $295 \mathrm{~nm}$. As shown in Figure 6, when the concentration of berberine was increased from 0 to $3.4 \mu \mathrm{M}$, the fluorescence intensity of VASP decreased with no significant shift of the maximum fluorescence emission wavelength. The plot of the fluorescence intensity vs. berberine concentration was approximately linear within this range. The $K \mathrm{~d}$ of berberine derived from the binding curve was $1 \times 10^{-7} \mathrm{M}$, approximately equal to the reciprocal of $K_{\mathrm{b}}$ (constant binding). These data indicate that berberine directly binds to VASP.

\section{Berberine targets VASP's EVH1 domain and alters its configuration}

We next aimed to determine the exact binding site of berberine on the VASP protein. We employed the AutoDock software to configure the most favorable binding site of berberine on the EVH1 domain of VASP, which contains a hydrophobic cluster. The most favorable binding mode of berberine (purple structure) on the EVH1 domain of VASP is shown in Figure 7A. Furthermore, the far-UV CD spectrum of VASP alone exhibited an intense negative maximum at $208 \mathrm{~nm}$ and a less intense negative maximum at $222 \mathrm{~nm}$, suggesting the presence of a significant amount of $\alpha$-helical structure. However, in the presence of berberine $(0.05 \mu \mathrm{M})$, the negative maxima at both 208 and $222 \mathrm{~nm}$ were reduced, suggesting a decrease of $\alpha$-helical structure. When the concentration of berberine reached $0.5 \mu \mathrm{M}$, the negative maximum at 222

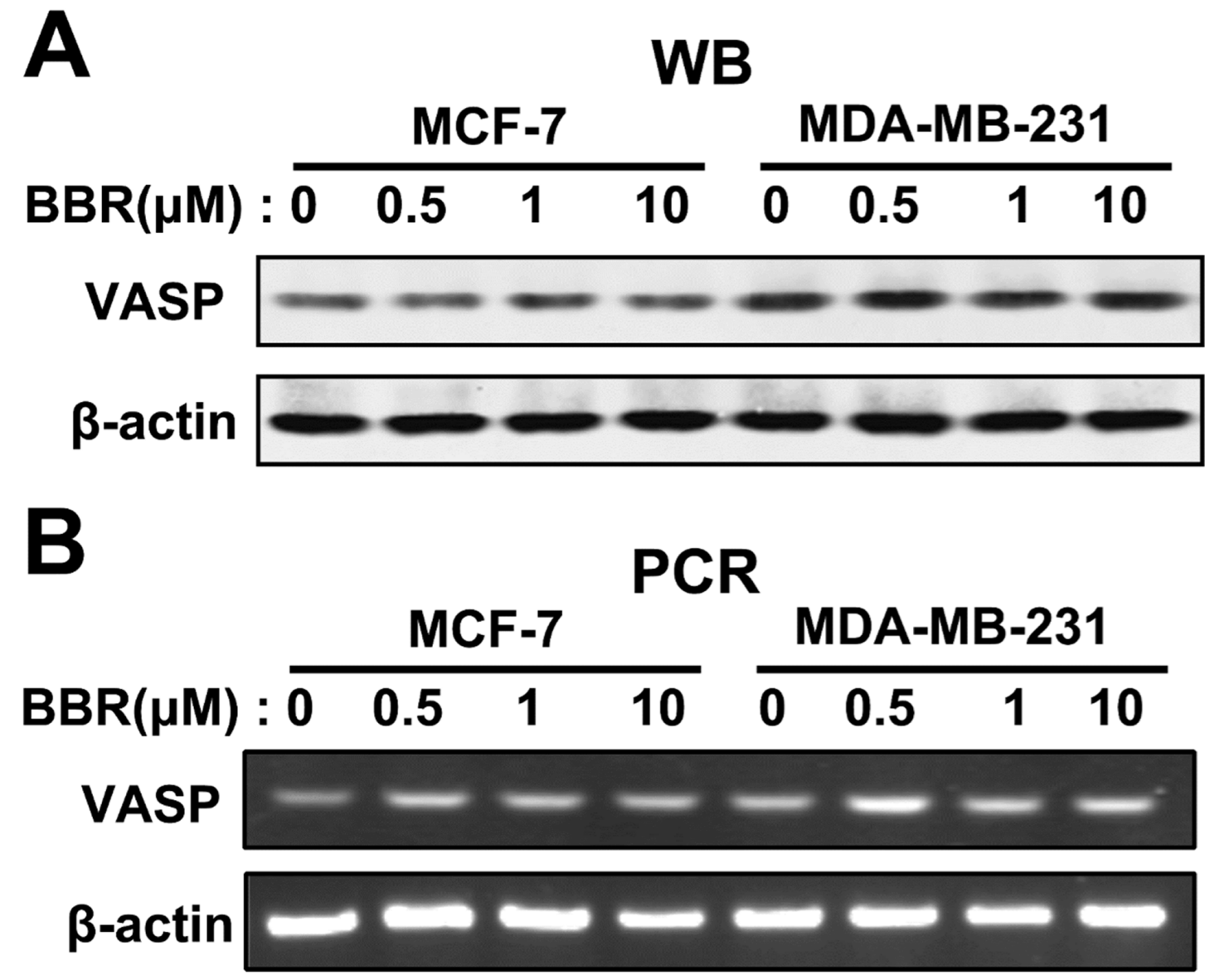

Figure 5: Berberine does not affect expression of VASP. MDA-MB-231 and MCF-7 cells were treated with different concentrations of berberine for $48 \mathrm{~h}$. A. Western blot analysis of VASP protein level, using $\beta$-actin as a loading control. B. RT-PCR analysis of VASP mRNA expression level. 
A

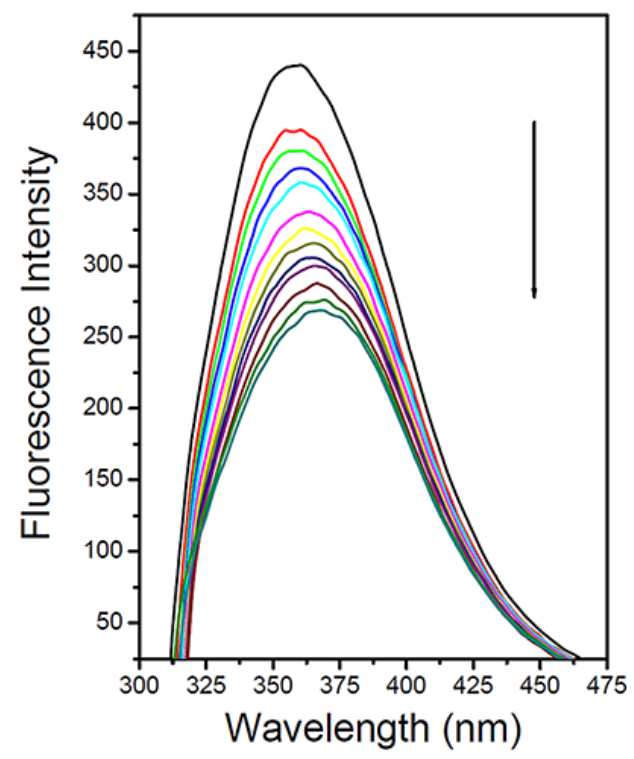

B

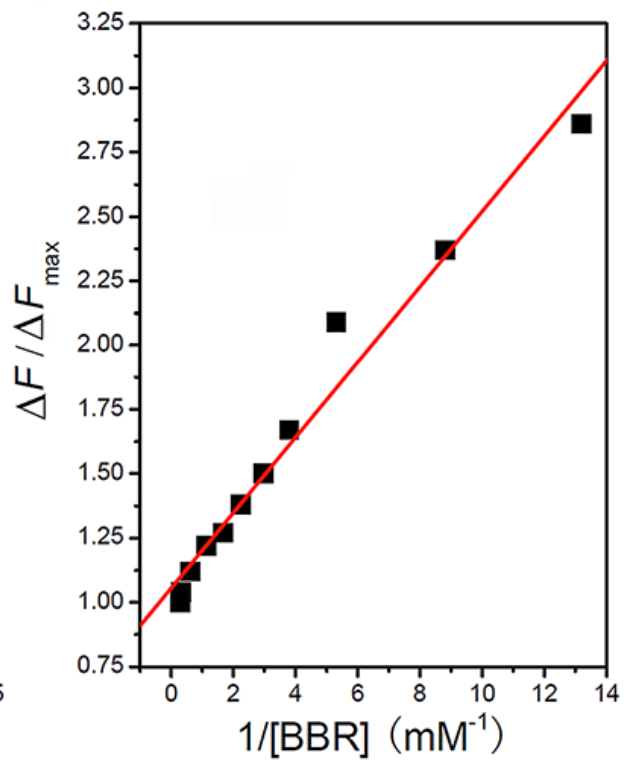

Figure 6: Berberine binds to VASP. A. When berberine concentration was increased from 0 to $3.4 \mu \mathrm{M}$, the fluorescence intensity of VASP decreased and showed no significant shift in the maximum fluorescence emission wavelength. B. Plot of fluorescence intensity $v s$. berberine concentration.


Figure 7: Berberine binds to the EVH1 domain of VASP and affects the far-UV CD spectra of VASP protein. A. The most favorable binding mode of berberine (berberine) to the EVH1 domain of VASP. B. Far-UV CD spectra of VASP protein. The concentration of VASP was $2.18 \mu \mathrm{M}$. Berberine concentration ranged from 0 to $5 \mu \mathrm{M}$. Band width was $1 \mathrm{~nm}$, response was $2 \mathrm{~s}$, measurement range was 250-190 nm, data pitch was $1 \mathrm{~nm}$, scanning speed was $200 \mathrm{~nm} / \mathrm{min}$, and cell length was $0.1 \mathrm{~cm}$. 
nm was no longer detectable. However, a partial recovery of the negative maximum at $222 \mathrm{~nm}$ was observed when the concentration of berberine was increased to $5 \mu \mathrm{M}$ (Figure 7B). Collectively, these results indicate that berberine binds to VASP's EVH1 domain and alters its conformation.

\section{Berberine inhibits actin polymerization via VASP}

Having demonstrated that berberine binds to the VASP, we next tested whether this interaction interfered with VASP's activity. F-actin examined by pyrene fluorescence was used as an indicator of actin assembly. F-actin exhibited dynamic instability (auto assembly-disassembly) in the absence of VASP (no purified VASP added to the reaction system) but polymerized more stably upon VASP addition in MDA-MB-231 and MCF-7 cells (Figure 8A). As expected, berberine reduced the amount of F-actin and destabilized F-actin filaments in a dosage-dependent manner, indicating an inhibitory effect of berberine on actin assembly in these breast cancer cells (Figure 8B). Consistently, fewer actin aggregates and bundled stress fibers were observed with increasing berberine concentration up to $1 \mathrm{M}$, whereas stress fibers gathered by F-actin appeared long and regular in control cells (Figure 9). Moreover, no stress fibers were observed in the cortical pool with only some irregular actin filaments scattered around the cell periphery even when the berberine concentration was as low as $5 \mu \mathrm{M}$ (Figure 9). Also, the intensity and distribution of cytoplasmic VASP was not altered (Figure 9). Taken together, these data suggest that berberine inhibits actin polymerization by blocking VASP activity in breast cancer cells.

\section{DISCUSSION}

Breast cancer is one of the malignancies with highest incidence and mortality, causing $\sim 411,000$ yearly deaths among women worldwide [21, 22]. Basallike breast cancer is resistant to endocrine and targeted Herceptin therapies, making it one of the most difficult types of cancer to treat, with poor prognosis [10] even after routine systemic chemotherapy treatment [9].

Although previous studies have revealed many potential biomarkers associated with poor prognosis in basal-like breast cancer, including basal cytokeratins (CK5/6, CK14, CK17), epidermal growth factor receptor (EGFR), c-kit, P63, P-cadherin and FOXC1, currently, there are no targeted treatments. Elevated levels of the actin-associated protein VASP in lung adenocarcinoma correlate with the degree of de-differentiation and poor pathological stage [23]. Moreover, Liu et al. showed that VASP overexpression promotes neoplastic transformation in wild-type NIH 3T3 cells [24]. Furthermore, we previously showed that VASP promotes breast cancer cell migration and that VASP levels are higher in basal-like than in luminal breast cancer $[17,18]$. In addition, VASP levels are higher in basal-like MDA-MB-231 cells than in luminal type MCF-7 cells. These data suggest that VASP may serve as a therapeutic target to treat basal-like breast cancer.
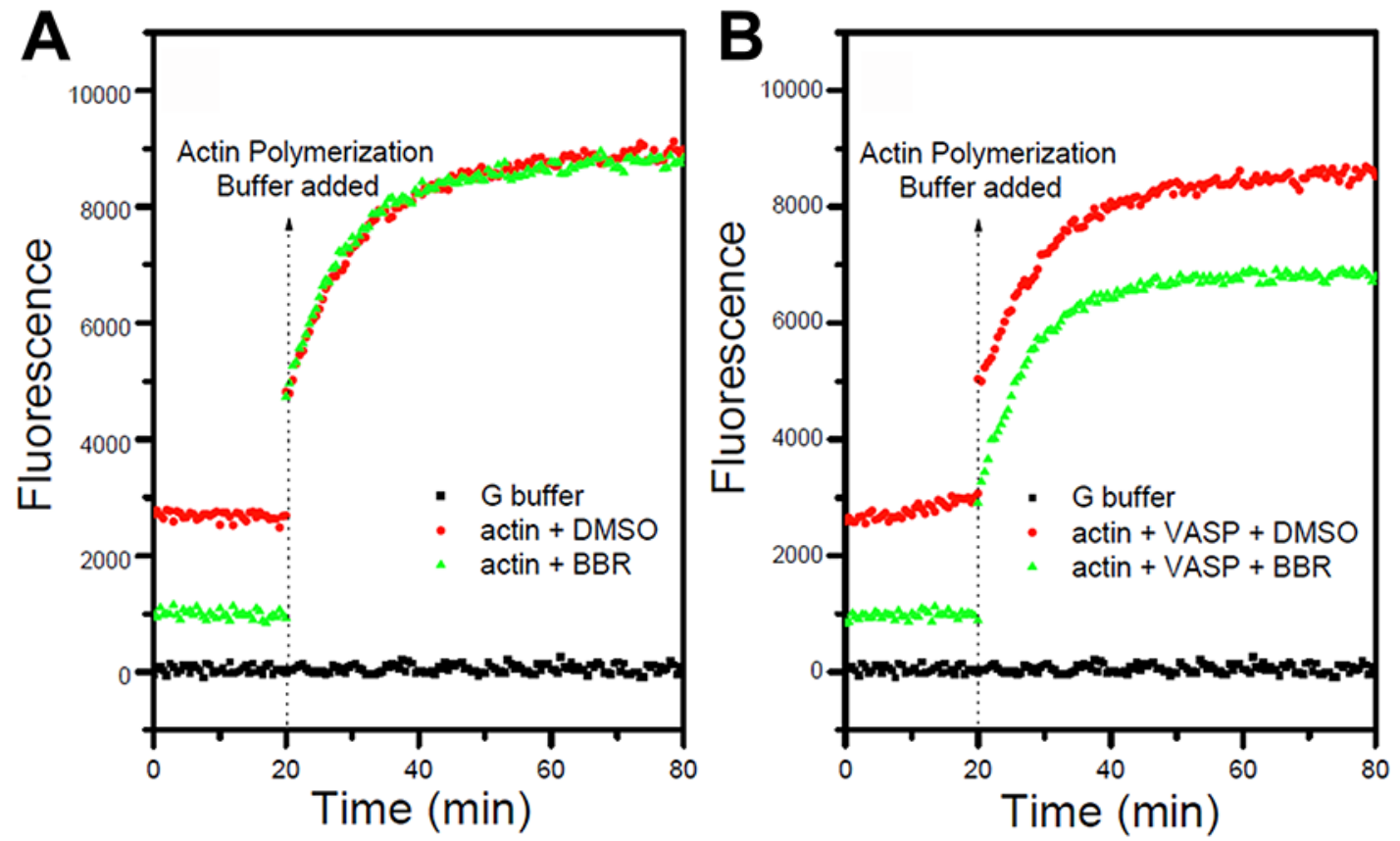

Figure 8: Berberine inhibits actin polymerization in the presence of VASP. Polymerization was determined according to increasing pyrene fluorescence. Berberine (berberine) had a quenching effect on the fluorescence signal of pyrene-actin. A. Berberine had no effect on actin polymerization with the addition of actin polymerization buffer. B. In the presence of $0.5 \mu \mathrm{M}$ VASP, the inhibitory effect of berberine remained and reduced the final amount of F-actin. 
VASP is a widespread actin-related protein that locates to highly dynamic regions of the cell membrane, and participates in biological processes that depend on actin (F-actin) assembly/disassembly, such as adhesion, spreading, migration, invasion and metastasis [25-28]. The VASP protein consists of three functional domains: an Ena/VASP homology 1 (enabled/vasodilator-stimulated phosphoprotein homology 1, EVH1) domain at the $\mathrm{N}$-terminus, a central proline-rich region (PRR), and an Ena/VASP homology domain 2 (enabled/vasodilatorstimulated phosphoprotein homology 2, EVH2) at the C-terminus [29]. The N-terminal EVH1 domain mediates VASP anchoring to promote actin filament assembly by recognizing "FPPPP" motifs within other cytoskeletonassociated proteins [30]. This allows for the recruitment of VASP by various proteins to cell-cell junctions [31], cell-extracellular matrix adhesion plaques [32], the end of actin filaments [29], and bacterial membrane surfaces [33]. The VASP EVH1 domain possesses a hydrophobic $\beta$-barrel fold, with seven $\beta$-strands packed together to form an antiparallel $\beta$-sandwich at the $\mathrm{N}$ terminus, and an $\alpha$-helix at the C-terminus. EVH1-mediated recognition and anchoring is a prerequisite for recruitment of profilin-actin complexes by the PRR region $[26,34]$ and binding of actin filaments by the EVH2 domain [27, 29]. These interactions, enable VASP to promote actin filament elongation $[29,35]$ and cell migration. On the other hand, berberine inhibits cell migration. Therefore, we hypothesized that berberine acts as a tumor suppressor by binding VASP to impair cell migration in breast cancer cells.

Berberine is a derivative of quaternary ammonium with conjugated double bonds. Its structure is characterized by the combination of two isoquinolines. Our structural and electronic distribution analyses show unpaired electron orbits in the oxygen atoms of the 1,2-methylenedioxy, vertically aligned with the electron orbit of benzene ring $\mathrm{A}$ and a positive charge of the $\mathrm{N}$ atom, which confers slight hydrophilicity. Therefore, we hypothesized that berberine specifically binds to the gap in VASP's EVH1 region, thereby inhibiting VASP's ability to promote actin assembly. Indeed, we found in our present study that although berberine does not affect VASP protein and mRNA levels (Figure 4), it can bind VASP and affect its structure (Figure 6 and 7), thereby inhibiting actin polymerization (Figure 8 and 9).

Previous studies showed that $100-500 \mu \mathrm{M}$ berberine (pretreatment for $24 \mathrm{~h}$ ) inhibits the growth of breast cancer cells by more than 50\% [25, 36]. Additionally, $10 \mu \mathrm{M}$ berberine inhibits migration in breast cancer MCF-7 and MDA-MB-231 cells [25, 37, 38]. Our current study confirms such findings. In addition, our data show that basal-like breast cancer MDA-MB-231 cells are more sensitive to berberine's inhibitory effects on cell migration than MCF-7 cells. Furthermore, we propose a molecular mechanism for this inhibition, showing that berberine inhibits VASP and thereby actin polymerization. Importantly, the concentrations of berberine used in our studies $(0.1-50 \mu \mathrm{M})$ are physiologically relevant since the concentration of berberine in human plasma remains low $(\sim 40 \mu \mathrm{M})$ at conventional oral dosage [36].

Various mechanisms have been proposed for berberine's tumor suppressor functions in several types of cancer, including colonic adenomas and adenocarcinomas [39, 40], esophageal cancer [41], colon cancer [42], nasopharyngeal carcinoma [43], and lung cancer [36]. Although these studies revealed that berberine can exert antitumor effects through many different pathways, including the promotion of senescence [44-

\section{BBR}

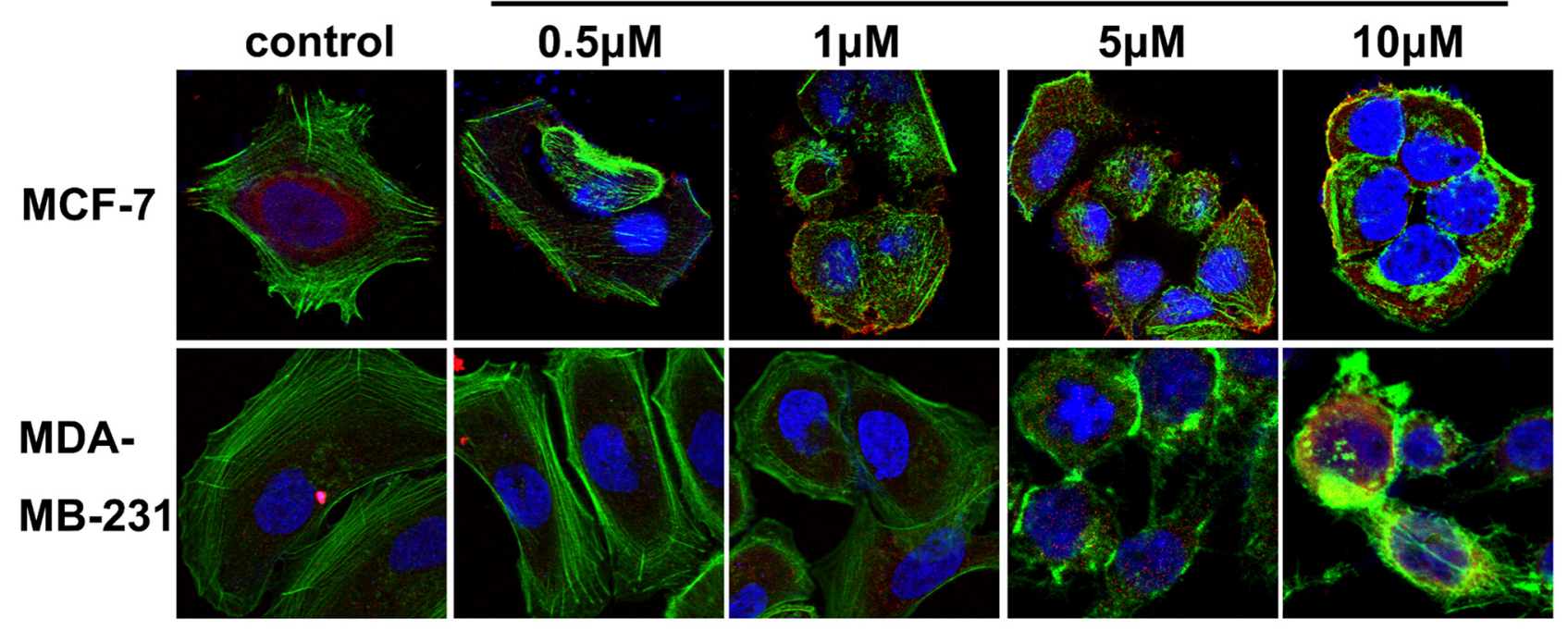

Figure 9: Berberine inhibits the formation of F-actin. Representative confocal microscopy images from 3 separate experiments of MDA-MB-231 and MCF-7 cells $3 \mathrm{~h}$ after berberine treatment (0.5-10 $\mu \mathrm{M})$. F-actin (stained with phalloidin): green; VASP: red; and nuclei: blue. Original magnification $\times 1,000$. 
46] and apoptosis [14] in cancer cells, as well as tumor microenvironment remodeling [47], further studies are needed to propose a comprehensive model that explains the antitumor actions of berberine in various types of cancer.

Here, we elucidated a novel mechanism by which berberine inhibits basal-like breast cancer cell proliferation and migration. Our findings provide a rationale for clinical trials to treat basal-like breast cancer, a very aggressive and treatment-resistant type of cancer.

\section{MATERIALS AND METHODS}

\section{Cell culture}

The breast cancer cell lines MDA-MB-231 and MCF-7 were obtained from Cell Bank of Type Culture Collection of Chinese Academy of Sciences (Shanghai, China). MDA-MB-231 cells were cultured in RPMI-1640 medium (HyClone, Logan, UT, USA) supplemented with $10 \%$ fetal bovine serum (FBS) (HyClone, Logan, UT, USA), $100 \mathrm{U} / \mathrm{mL}$ penicillin and $100 \mu \mathrm{g} / \mathrm{mL}$ streptomycin under the conditions of $37{ }^{\circ} \mathrm{C}$ and $5 \% \mathrm{CO}_{2}$. MCF-7 cells were maintained in Eagle's minimum essential medium (MEM) supplemented with $10 \%$ FBS, $100 \mathrm{U} / \mathrm{mL}$ penicillin and $100 \mu \mathrm{g} / \mathrm{mL}$ streptomycin.

\section{MTT assay}

Cell viability was determined using MTT assay (Amresco, Solon, OH, USA). Briefly, $5 \times 10^{4} / \mathrm{ml}$ cells per well were plated in 96-well plates and incubated for $24 \mathrm{~h}$. The cells were then treated with different concentrations (0, $1 \mathrm{nM}, 10 \mathrm{nM}, 100 \mathrm{nM}, 1 \mu \mathrm{M}, 10 \mu \mathrm{M}, 20 \mu \mathrm{M}, 50 \mu \mathrm{M}$, $100 \mu \mathrm{M}$ and $500 \mu \mathrm{M}$ ) of berberine (Sigma-Aldrich, St. Louis, MO, USA) for $24 \mathrm{~h}$. Then the cells were treated with $20 \mu \mathrm{l}$ of $5 \mathrm{mg} / \mathrm{ml} \mathrm{MTT}$ and incubated for $4 \mathrm{~h}$ at $37{ }^{\circ} \mathrm{C}$. Then the medium was discarded, and $200 \mu \mathrm{l}$ of dimethylsulfoxide (DMSO) (Sigma-Aldrich, St. Louis, MO, USA) was added. Absorbance was measured at $570 \mathrm{~nm}$ with an ELISA plate reader (Infinite ${ }^{\circledR} 200$ PRO, TECAN, Männedorf, $\mathrm{CH}$ ). The viability of berberinetreated cells was calculated by comparing to vehicletreated cells, which were arbitrarily assigned $100 \%$. The experiments were performed in triplicate, independently.

\section{Cell migration assay}

Migration of MDA-MB-231 and MCF-7 cells was evaluated using $6.5 \mathrm{~mm}$ Transwell ${ }^{\circledR}$ chambers with 8.0 $\mu \mathrm{m}$ pores size polycarbonate membrane filters (Corning Costar, Corning, NY). Cells $\left(2.5 \times 10^{4}\right)$ suspended in 0.1 $\mathrm{ml}$ serum-free medium in the presence or absence of berberine were seeded onto the upper chamber. Half a milliliter of medium containing $10 \% \mathrm{FBS}$ was added to the bottom chamber. After $36 \mathrm{~h}$ or $48 \mathrm{~h}$ treatment with berberine, filter inserts were removed from the wells. The cells on the upper surface of the filter were wiped with a cotton swab. Filter membranes were stained with $0.1 \%$ crystal violet (Sigma-Aldrich, St. Louis, MO, USA) for $30 \mathrm{~min}$, and the invaded cells were quantified by counting 5 fields at a magnification of $\times 100$. Each experiment was repeated in triplicate and the mean value was computed.

\section{Clinical samples}

This study was approved by Ethics Commission of the School of Medicine of Wuhan University. Breast cancer samples $(n=41)$ were obtained from patients recruited at Zhongnan Hospital of Wuhan University between January 1, 2009 and December 30, 2012, who had never been treated with anti-cancer drugs or neoadjuvant chemotherapy. The samples were sectioned and fixed overnight in $10 \%$ buffered formalin. The samples were immunohistochemically stained for ER, PR, and HER2 and were independently interpreted by 2 pathologists. Invasive breast carcinomas with weak, moderate, or strong nuclear labeling for ER or PR in greater than $1 \%$ of cells were considered $\mathrm{ER}+$ or $\mathrm{PR}+$, respectively, in accordance with the ASCO/CAP ER and PgR guideline [48]. Her2+ samples had a $3+$ (strong positive) immunohistochemical score or a Her2 fluorescence in situ hybridization amplification ratio $>4$ [49]. Samples with ambiguous ratios (1.8-2.2) or low-level amplification (ratios, 2.2-4.0) were excluded.

\section{Immunohistochemical analysis}

For paraffin-embedded breast cancer tissues, $5 \mu \mathrm{m}$ thick sections were deparaffinized in xylene, followed by treatment with a graded series of alcohol $(100,95$, and $80 \%, \mathrm{v} / \mathrm{v}$ ) and rehydration in PBS ( $\mathrm{pH} 7.5)$. Sections were microwaved 5 min for antigen retrieval and incubated with 3\% hydrogen peroxide in methanol $(\mathrm{v} / \mathrm{v})$ for 12 min to block endogenous peroxidase. Next, the sections were washed with PBS ( $\mathrm{pH} 7.5)$, and incubated in protein blocking solution $(0.5 \%$ normal goat serum in PBS, v/v) for $30 \mathrm{~min}$. The sections were then incubated with antibody against human VASP (1:200, ENZO Life Sciences, Farmingdale, NY) in a humidified chamber for $2 \mathrm{~h}$ at $37^{\circ} \mathrm{C}$, rinsed with PBS 3 times, and incubated with peroxidase-conjugated secondary antibody (1:200, Jackson ImmunoResearch, West Grove, PA) for $1 \mathrm{~h}$ at room temperature. To detect positive reactions, the slides were incubated with stable 3,39-diaminobenzidine (DAB) for 5-10 min (Zhongshan Jingqiao Biotechnology, Beijing, China). The sections were rinsed with distilled water, counterstained with Gill's hematoxylin for 1 min (Sigma, St. Louis, MO), and observed under a BX53 Olympus microscope. Mean density of the sections was analyzed using Image-Pro Plus 4.5 software. The staining intensity of VASP was scored as negative $(-)$, weak $(+)$, moderate, $(++)$, or strong $(+++)$, as described previously $[7,50]$. 


\section{Western blot analysis}

Cells were harvested at the indicated time and lysed using routine procedures. Proteins were separated on a $10 \%$ SDS-polyacrylamide gel and transferred to polyvinylidene difluoride membranes. The membranes were then blotted with antibody for VASP (1:1000, ENZO Life Sciences, Farmingdale, NY, USA) or $\beta$-actin (1:500, Santa Cruz Biotechnology, Santa Cruz, CA, USA). The signal was visualized with an alkaline phosphataseconjugated anti-rabbit or mouse IgG antibody (1:2000, Jackson ImmunoResearch, West Grove, PA). All experiments were performed in triplicate.

\section{Reverse transcription PCR (RT-PCR)}

Total RNA was extracted from cells using Trizol reagent (Invitrogen, Carlsbad, CA). Total RNA $(3 \mu \mathrm{g})$ was used for first-strand cDNA synthesis with RevertAidTM First Strand cDNA Synthesis Kit (Fermentas, Vilnius, LTU). PCR amplification of cDNA was performed using the following specific primers: VASP: forward: 5'-GCGCCTGGTACCATGACGCAAGT TGGGGAGAAAACC-3' and reverse: 5'-GCG CCTGGA TCCCAGGGAGAACCCCGCTTCC-3'; $\beta$-actin forward: 5'-CATTAAGGAGAAGCTGTGCT-3' and reverse: 5'-GTTGAAGGTAGTTT CGTGGA -3'. The PCR products were visualized by electrophoresis on a $2 \%$ agarose gel $(\mathrm{w} / \mathrm{v})$.

\section{Intrinsic fluorescence spectroscopy}

VASP protein was expressed in E. coli Rosetta by induction with $0.5 \mathrm{mM}$ isopropyl-1-thio- $\beta$-Dgalactopyranoside (IPTG) at $18{ }^{\circ} \mathrm{C}$ for $16 \mathrm{~h}$ as previously described $[51,52]$. The intrinsic fluorescence spectroscopy was used to investigate the interaction between berberine with VASP at $25^{\circ} \mathrm{C}$ by $\mathrm{LS}-55$ luminescence spectrometer (Perkin-Elmer Life Sciences, Shelton, CT). An excitation wavelength of $295 \mathrm{~nm}$ was used for intrinsic fluorescence measurements, and the emission spectra were recorded between 300 and 475 $\mathrm{nm}$. The excitation and emission slits were both at 15 $\mathrm{nm}$, and the scan speed was $1,000 \mathrm{~nm} / \mathrm{min}$. Six hundred $\mu \mathrm{l}$ of $\operatorname{VASP}(0.4 \mu \mathrm{M})$ were placed in a $1 \mathrm{~mm}$ thermostated quartz fluorescence cuvette and successively titrated with $22.8 \mu \mathrm{M}, 91.2 \mu \mathrm{M}$ and $0.18 \mathrm{mM}$ berberine with continuous stirring. The fluorescence measurements were performed with protein samples that had an optical density at $280 \mathrm{~nm}$ of less than 0.1 to avoid the inner filter effects [53]. Buffer titrated with an equivalent amount of berberine was also measured under the same conditions as control to analyze fluorescence of the samples. Each spectrum was measured three times to acquire the final fluorescence emission spectra. The plot was fitted to the following equation: $\Delta F / \Delta F \max =$ [berberine] $/([$ berberine $]+K \mathrm{~d})$, where $\Delta F$ is the change of fluorescence intensity after each injection, $\Delta F \max$ is the maximum fluorescence intensity change, and [berberine] is the concentration of berberine.

\section{Docking of berberine to EVH1 domain of VASP}

The data for the computational modeling in this study were derived from the recent NMR structure of EVH1 (PDB ID 1EGX). The best representative conformer (structure 1) in this ensemble (total of 20 structures) was chosen for docking and assignment with Kollman-UTI charges in the Amber 4.0 force field. The structure of BER was manually constructed according to the standard bond lengths and angles, minimized by a molecular mechanical method and then optimized in the Tripos force field with Gasteiger-Hückel charges. The docking calculations were performed with the software package AutoDock Vina [54], in which the Lamarckian Genetic Algorithm was applied. In each calculation, the initial structure of the ligand was in an arbitrary conformation as well as orientation and position. After 100 runs, the most favorable binding model was selected according to the binding energy and geometry match.

\section{Circular dichroism (CD) spectroscopy}

The far-UV CD spectra were measured with a Jasco J-810 spectropolarimeter (Jasco Corporation, Tokyo, Japan) using a $0.1 \mathrm{~cm}$ path length cylindrical cell at $190-$ $250 \mathrm{~nm}$ (protein secondary structure) at $25^{\circ} \mathrm{C}$. The band width was set to $1 \mathrm{~nm}$, while the response time was 1 s. VASP was thoroughly mixed in buffer $(50 \mathrm{mM}$ Tris$\mathrm{HCl}, \mathrm{pH}$ 7.5, $100 \mathrm{mM} \mathrm{NaCl}, 1 \mathrm{mM}$ tris-(2-carboxyethyl) phosphine, TCEP) with different concentrations of berberine and allowed to equilibrate thermally for 4 min prior to the $\mathrm{CD}$ measurements. Each sample spectrum was corrected by subtracting from the spectrum (baseline) recorded for the buffer containing an equivalent concentration of berberine. The relative change in the $\alpha$-helical content of VASP, represented by the relative change in molar ellipticity of VASP at $222 \mathrm{~nm}$, was calculated from the CD spectra [55]. Each spectrum was an average of three different scans obtained by collecting data at $1 \mathrm{~nm}$ intervals with a scan speed of $200 \mathrm{~nm} / \mathrm{min}$.

\section{Actin polymerization assay}

Actin polymerization assay was performed using the kit from Cytoskeleton (Denver, CO, USA). Briefly, pyrene actin $(0.4 \mathrm{mg} / \mathrm{ml}, 200 \mu \mathrm{l})$ in G-buffer $(5 \mathrm{mM}$ Tris, $0.2 \mathrm{mM} \mathrm{CaCl}$, and $0.2 \mathrm{mM}$ ATP, $\mathrm{pH} 8.0$ ) was prepared according to the manufacturer's recommendations. The actin polymerization reaction system was mixed with $20 \mu \mathrm{l}$ of $5 \mu \mathrm{M}$ VASP in $1 \times$ KMEI $(50 \mathrm{mM} \mathrm{KCl}, 1 \mathrm{mM} \mathrm{MgCl}, 1 \mathrm{mM}$ EGTA, and 10 $\mathrm{mM}$ imidazole, $\mathrm{pH}$ 7.0) in the presence or absence of $5 \mu \mathrm{M}$ berberine was added to (The final concentration of VASP and berberine were $0.5 \mu \mathrm{M}$ ). After $20 \mathrm{~min}$, polymerization reaction 
was initiated by adding $20 \mu \mathrm{l} 10 \times$ actin polymerization buffer $(0.5 \mathrm{mM} \mathrm{KCl}, 20 \mathrm{mM} \mathrm{MgCl}, 10 \mathrm{mM}$ ATP $)$ to convert $\mathrm{Ca}^{2+}$-ATP-actin to $\mathrm{Mg}^{2+}$-ATP-actin. Pyrene fluorescence was measured with a Spectramax M2 Microplate Reader (Molecular Device) with an excitation wavelength of $360 \mathrm{~nm}$ and an emission wavelength of $410 \mathrm{~nm}$.

\section{Immunofluorescence staining}

MCF-7 and MDA-MB-231 cells were cultured on coverslips in a 24 -well plate. Cells were fixed with $4 \%$ paraformaldehyde for $30 \mathrm{~min}$ at room temperature, washed, and permeabilized with $0.5 \%$ Triton $X-100$ for $5 \mathrm{~min}$. The cells were incubated with antibody for VASP $(1: 100$, ENZO Life Sciences, Farmingdale, NY, USA) at $4{ }^{\circ} \mathrm{C}$ overnight followed by incubation with secondary antibody conjugated to TRITC (1:100, Jackson ImmunoResearch, West Grove, PA, USA). Double staining was conducted continuously with phalloidin-Alexa 488 (1:40, Invitrogen, Carlsbad, CA). ProLong Gold Antifade reagent along with DAPI (Invitrogen) was used to mount the coverslips to slides.

\section{In vivo tumor xenograft model}

Animal experiments were performed following the Guide for the Care and Use of Laboratory Animals of Wuhan University. Female athymic mice 6 weeks of age (nu/nu) on a BALB/c background (Hunan SJA Laboratory, Permission number: HNASLKJ20120623) were raised in a pathogen-free isolation facility with a light/dark cycle of $12 / 12 \mathrm{~h}$ and ad libitum fed with rodent chow and water. MDA-MB-231 cells $\left(1 \times 10^{7}\right)$ in $200 \mu$ culture medium were subcutaneously injected into the right hind flank. Animalbearing tumors were randomly assigned to treatment groups (6 mice per group). When tumor grew to $100 \mathrm{~mm}^{3}$, the mice were divided into 3 subgroups. The first group received an intraperitoneal injection of berberine $(10 \mathrm{mg} / \mathrm{kg})$ every 4 days, while the second group received an injection of vehicle (DMSO) only, and the third group received injection of doxorubicin $(4 \mathrm{mg} / \mathrm{kg})$. Mice were monitored up to 12-20 days after initiation of treatment. Tumor size was monitored by measuring the length and width with calipers every 4 days, and volumes were calculated with the formula: $\mathrm{L} \times \mathrm{W}^{2} / 2=\mathrm{mm}^{3}$, where $\mathrm{L}$ is the length and $\mathrm{W}$ the width of the tumor [10]. Kaplan-Meier survival analysis and log-rank test were used to analyze mice survival. When the mice were sacrificed, the tumors and livers were fixed in $4 \%$ paraformaldehyde, sectioned, and stained with hematoxilineosine for light microscopic analysis.

\section{Statistical analysis}

All results were presented as the mean \pm standard error of mean. Statistical analysis of data having equal variance was performed by one-way or two-way analysis of variance (ANOVA) followed by Tukey's Post Hoc test when appropriate. Chi-square test was used for intergroup comparison for immunohistochemical analysis of VASP expression, considering $p<0.05$ as statistically significant.

\section{ACKNOWLEDGMENTS}

We thank Wenhua Li and Yanru Su for advice and stimulating discussion; Chengpeng Fan and Xiaoyang Wan for critical reading of the manuscript; Wei Wang and Zhongliang Zheng for excellent technical assistance in drug and protein docking.

\section{FUNDING}

This study was supported by the National Natural Science Foundation of China (grants 81472765, 81572943, 31570353 and 31170328) and the Fundamental Research Funds for the Central Universities (grant No. 2042014kf0189).

\section{CONFLICTS OF INTEREST}

The authors declare no conflicts of interest.

\section{REFERENCES}

1. Jemal A, Bray F, Center MM, Ferlay J, Ward E and Forman D. Global cancer statistics. CA Cancer J Clin. 2011; 61:69-90.

2. Coleman. WB and Tsongalis GJ. Cancer Epidemiology: Incidence and Etiology of Human Neoplasms. The Molecular Basis of Human Cancer, Humana Press. 2002:pp.3-22.

3. Goldhirsch A, Wood WC, Coates AS, Gelber RD, Thurlimann B and Senn HJ. Strategies for subtypes-dealing with the diversity of breast cancer: highlights of the St. Gallen International Expert Consensus on the Primary Therapy of Early Breast Cancer 2011. Ann Oncol. 2011; 22:1736-1747.

4. Ihemelandu CU, Leffall LD, Jr., Dewitty RL, Naab TJ, Mezghebe HM, Makambi KH, Adams-Campbell L and Frederick WA. Molecular breast cancer subtypes in premenopausal and postmenopausal African-American women: age-specific prevalence and survival. J Surg Res. 2007; 143:109-118.

5. Kim MJ, Ro JY, Ahn SH, Kim HH, Kim SB and Gong G. Clinicopathologic significance of the basal-like subtype of breast cancer: a comparison with hormone receptor and Her2/neu-overexpressing phenotypes. Hum Pathol. 2006; 37:1217-1226.

6. Zhao J, Liu H, Wang M, Gu L, Guo X, Gu F and Fu L. Characteristics and prognosis for molecular breast cancer subtypes in Chinese women. J Surg Oncol. 2009; 100:89-94. 
7. Carey LA, Perou CM, Livasy CA, Dressler LG, Cowan D, Conway K, Karaca G, Troester MA, Tse CK, Edmiston S, Deming SL, Geradts J, Cheang MC, Nielsen TO, Moorman PG, Earp HS, et al. Race, breast cancer subtypes, and survival in the Carolina Breast Cancer Study. JAMA. 2006; 295:2492-2502.

8. Onitilo AA, Engel JM, Greenlee RT and Mukesh BN. Breast cancer subtypes based on ER/PR and Her2 expression: comparison of clinicopathologic features and survival. Clin Med Res. 2009; 7:4-13.

9. Cheang MC, Chia SK, Voduc D, Gao D, Leung S, Snider J, Watson M, Davies S, Bernard PS, Parker JS, Perou CM, Ellis MJ and Nielsen TO. Ki67 index, HER2 status, and prognosis of patients with luminal B breast cancer. J Natl Cancer Inst. 2009; 101:736-750.

10. Cheang MC, Voduc D, Bajdik C, Leung S, McKinney S, Chia SK, Perou CM and Nielsen TO. Basal-like breast cancer defined by five biomarkers has superior prognostic value than triple-negative phenotype. Clin Cancer Res. 2008; 14:1368-1376.

11. Imanshahidi $M$ and Hosseinzadeh H. Pharmacological and therapeutic effects of Berberis vulgaris and its active constituent, berberine. Phytother Res. 2008; 22:999-1012.

12. Sun Y, Xun K, Wang Y and Chen X. A systematic review of the anticancer properties of berberine, a natural product from Chinese herbs. Anticancer Drugs. 2009; 20:757-769.

13. Tang J, Feng Y, Tsao S, Wang N, Curtain R and Wang Y. Berberine and Coptidis rhizoma as novel antineoplastic agents: a review of traditional use and biomedical investigations. J Ethnopharmacol. 2009; 126:5-17.

14. Patil JB, Kim J and Jayaprakasha GK. Berberine induces apoptosis in breast cancer cells (MCF-7) through mitochondrial-dependent pathway. Eur J Pharmacol. 2010; 645:70-78.

15. Kim JB, Yu JH, Ko E, Lee KW, Song AK, Park SY, Shin I, Han W and Noh DY. The alkaloid Berberine inhibits the growth of Anoikis-resistant MCF-7 and MDA-MB-231 breast cancer cell lines by inducing cell cycle arrest. Phytomedicine. 2010; 17:436-440.

16. Ranson M, Tian Z, Andronicos NM, Rizvi S and Allen BJ. In vitro cytotoxicity of bismuth-213 (213Bi)-labeledplasminogen activator inhibitor type 2 (alpha-PAI-2) on human breast cancer cells. Breast Cancer Res Treat. 2002; 71:149-159.

17. Han G, Fan B, Zhang Y, Zhou X, Wang Y, Dong H, Wei Y, Sun S, Hu M, Zhang J and Wei L. Positive regulation of migration and invasion by vasodilator-stimulated phosphoprotein via Rac1 pathway in human breast cancer cells. Oncol Rep. 2008; 20:929-939.

18. Zhang Y, Han G, Fan B, Zhou Y, Zhou X, Wei L and Zhang J. Green tea (-)-epigallocatechin-3-gallate down-regulates VASP expression and inhibits breast cancer cell migration and invasion by attenuating Rac1 activity. Eur J Pharmacol. 2009; 606:172-179.
19. Kim JB, Lee KM, Ko E, Han W, Lee JE, Shin I, Bae JY, Kim S and Noh DY. Berberine inhibits growth of the breast cancer cell lines MCF-7 and MDA-MB-231. Planta Med. 2008; 74:39-42.

20. Carmona G, Perera U, Gillett C, Naba A, Law AL, Sharma VP, Wang J, Wyckoff J, Balsamo M, Mosis F, De Piano M, Monypenny J, Woodman N, McConnell RE, Mouneimne G, Van Hemelrijck M, et al. Lamellipodin promotes invasive $3 \mathrm{D}$ cancer cell migration via regulated interactions with Ena/VASP and SCAR/WAVE. Oncogene. 2016; 35:51555169. doi: 10.1038/onc.2016.47.

21. Jemal A, Siegel R, Xu J and Ward E. Cancer statistics, 2010. CA Cancer J Clin. 2010; 60:277-300.

22. Parkin DM. Global cancer statistics in the year 2000. Lancet Oncol. 2001; 2:533-543.

23. Dertsiz L, Ozbilim G, Kayisli Y, Gokhan GA, Demircan A and Kayisli UA. Differential expression of VASP in normal lung tissue and lung adenocarcinomas. Thorax. 2005; 60:576-581.

24. Liu K, Li L, Nisson PE, Gruber C, Jessee J and Cohen $\mathrm{SN}$. Reversible tumorigenesis induced by deficiency of vasodilator-stimulated phosphoprotein. Mol Cell Biol. 1999; 19:3696-3703.

25. Krause M, Dent EW, Bear JE, Loureiro JJ and Gertler FB. Ena/VASP proteins: regulators of the actin cytoskeleton and cell migration. Annu Rev Cell Dev Biol. 2003; 19:541-564.

26. Reinhard M, Jarchau T and Walter U. Actin-based motility: stop and go with Ena/VASP proteins. Trends Biochem Sci. 2001; 26:243-249.

27. Bear JE, Loureiro JJ, Libova I, Fassler R, Wehland J and Gertler FB. Negative regulation of fibroblast motility by Ena/VASP proteins. Cell. 2000; 101:717-728.

28. Loureiro JJ, Rubinson DA, Bear JE, Baltus GA, Kwiatkowski AV and Gertler FB. Critical roles of phosphorylation and actin binding motifs, but not the central proline-rich region, for Ena/vasodilator-stimulated phosphoprotein (VASP) function during cell migration. Mol Biol Cell. 2002; 13:2533-2546.

29. Ferron F, Rebowski G, Lee $\mathrm{SH}$ and Dominguez R. Structural basis for the recruitment of profilin-actin complexes during filament elongation by Ena/VASP. EMBO J. 2007; 26:4597-4606.

30. Fedorov AA, Fedorov E, Gertler F and Almo SC. Structure of EVH1, a novel proline-rich ligand-binding module involved in cytoskeletal dynamics and neural function. Nat Struct Biol. 1999; 6:661-665.

31. Moody JD, Grange J, Ascione MP, Boothe D, Bushnell E and Hansen MD. A zyxin head-tail interaction regulates zyxin-VASP complex formation. Biochem Biophys Res Commun. 2009; 378:625-628.

32. Reinhard M, Rudiger M, Jockusch BM and Walter U. VASP interaction with vinculin: a recurring theme of interactions with proline-rich motifs. FEBS Lett. 1996; 399:103-107. 
33. Niebuhr K, Ebel F, Frank R, Reinhard M, Domann E, Carl UD, Walter U, Gertler FB, Wehland J and Chakraborty T. A novel proline-rich motif present in ActA of Listeria monocytogenes and cytoskeletal proteins is the ligand for the EVH1 domain, a protein module present in the Ena/ VASP family. EMBO J. 1997; 16:5433-5444.

34. Howe AK, Hogan BP and Juliano RL. Regulation of vasodilator-stimulated phosphoprotein phosphorylation and interaction with $\mathrm{Abl}$ by protein kinase $\mathrm{A}$ and cell adhesion. J Biol Chem. 2002; 277:38121-38126.

35. Sechi AS and Wehland J. ENA/VASP proteins: multifunctional regulators of actin cytoskeleton dynamics. Front Biosci. 2004; 9:1294-1310.

36. Peng PL, Hsieh YS, Wang CJ, Hsu JL and Chou FP. Inhibitory effect of berberine on the invasion of human lung cancer cells via decreased productions of urokinaseplasminogen activator and matrix metalloproteinase-2. Toxicol Appl Pharmacol. 2006; 214:8-15.

37. Subik K, Lee JF, Baxter L, Strzepek T, Costello D, Crowley P, Xing L, Hung MC, Bonfiglio T, Hicks DG and Tang P. The Expression Patterns of ER, PR, HER2, CK5/6, EGFR, Ki-67 and AR by Immunohistochemical Analysis in Breast Cancer Cell Lines. Breast Cancer (Auckl). 2010; 4:35-41.

38. Kim S, Choi JH, Kim JB, Nam SJ, Yang JH, Kim JH and Lee JE. Berberine suppresses TNF-alpha-induced MMP-9 and cell invasion through inhibition of AP-1 activity in MDA-MB-231 human breast cancer cells. Molecules. 2008; 13:2975-2985.

39. DuBois RN, Radhika A, Reddy BS and Entingh AJ. Increased cyclooxygenase-2 levels in carcinogen-induced rat colonic tumors. Gastroenterology. 1996; 110:1259-1262.

40. Sheng H, Shao J, Kirkland SC, Isakson P, Coffey RJ, Morrow J, Beauchamp RD and DuBois RN. Inhibition of human colon cancer cell growth by selective inhibition of cyclooxygenase-2. J Clin Invest. 1997; 99:2254-2259.

41. Iizuka N, Hazama S, Yoshimura K, Yoshino S, Tangoku A, Miyamoto K, Okita K and Oka M. Anticachectic effects of the natural herb Coptidis rhizoma and berberine on mice bearing colon 26/clone 20 adenocarcinoma. Int J Cancer. 2002; 99:286-291.

42. Wang L, Cao H, Lu N, Liu L, Wang B, Hu T, Israel DA, Peek RM, Jr., Polk DB and Yan F. Berberine inhibits proliferation and down-regulates epidermal growth factor receptor through activation of $\mathrm{Cbl}$ in colon tumor cells. PLoS One. 2013; 8:e56666.

43. Huang D, Wang W, Feng Z, Wang L, Chen Y, Xie C, Meng J and Tang F. Berberine inhibits the invasion and metastasis of nasopharyngeal carcinoma cells through Ezrin phosphorylation. Zhong Nan Da Xue Xue Bao Yi Xue Ban. 2011; 36:616-623.

44. Xiong YX, Su HF, Lv P, Ma Y, Wang SK, Miao H, Liu HY, Tan JH, Ou TM, Gu LQ and Huang ZS. A newly identified berberine derivative induces cancer cell senescence by stabilizing endogenous G-quadruplexes and sparking a DNA damage response at the telomere region. Oncotarget. 2015; 6:35625-35635. doi: 10.18632/oncotarget.5521.
45. Halicka HD, Zhao H, Li J, Lee YS, Hsieh TC, Wu JM and Darzynkiewicz Z. Potential anti-aging agents suppress the level of constitutive mTOR- and DNA damage- signaling. Aging (Albany NY). 2012; 4:952-965. doi: 10.18632/aging.100521.

46. Zhao H, Halicka HD, Li J and Darzynkiewicz Z. Berberine suppresses gero-conversion from cell cycle arrest to senescence. Aging (Albany NY). 2013; 5:623-636. doi: 10.18632/aging.100593.

47. Yu YN, Yu TC, Zhao HJ, Sun TT, Chen HM, Chen HY, An HF, Weng YR, Yu J, Li M, Qin WX, Ma X, Shen N, Hong J and Fang JY. Berberine may rescue Fusobacterium nucleatum-induced colorectal tumorigenesis by modulating the tumor microenvironment. Oncotarget. 2015; 6:3201332026. doi: 10.18632/oncotarget.5166.

48. Hammond ME, Hayes DF, Dowsett M, Allred DC, Hagerty KL, Badve S, Fitzgibbons PL, Francis G, Goldstein NS, Hayes M, Hicks DG, Lester S, Love R, Mangu PB, McShane L, Miller K, et al. American Society of Clinical Oncology/College of American Pathologists guideline recommendations for immunohistochemical testing of estrogen and progesterone receptors in breast cancer (unabridged version). Arch Pathol Lab Med. 2010; 134:e48-72.

49. Wolff AC, Hammond ME, Hicks DG, Dowsett M, McShane LM, Allison KH, Allred DC, Bartlett JM, Bilous M, Fitzgibbons P, Hanna W, Jenkins RB, Mangu PB, Paik S, Perez EA, Press MF, et al. Recommendations for human epidermal growth factor receptor 2 testing in breast cancer: American Society of Clinical Oncology/College of American Pathologists clinical practice guideline update. J Clin Oncol. 2013; 31:3997-4013.

50. Sihto H, Tynninen O, Butzow R, Saarialho-Kere U and Joensuu H. Endothelial cell KIT expression in human tumours. J Pathol. 2007; 211:481-488.

51. Hansen SD and Mullins RD. VASP is a processive actin polymerase that requires monomeric actin for barbed end association. J Cell Biol. 2010; 191:571-584.

52. Zhang JW, Su K, Shi WT, Wang Y, Hu PC, Wei L, Xiang $\mathrm{J}$ and Yang F. Matrine inhibits the adhesion and migration of BCG823 gastric cancer cells by affecting the structure and function of the vasodilator-stimulated phosphoprotein (VASP). Acta Pharmacol Sin. 2013; 34:1084-1092.

53. Li XM, Malakhova ML, Lin X, Pike HM, Chung T, Molotkovsky JG and Brown RE. Human glycolipid transfer protein: probing conformation using fluorescence spectroscopy. Biochemistry. 2004; 43:10285-10294.

54. Trott $\mathrm{O}$ and Olson AJ. AutoDock Vina: improving the speed and accuracy of docking with a new scoring function, efficient optimization, and multithreading. J Comput Chem. 2010; 31:455-461.

55. Xiang J, Fan JB, Chen N, Chen J and Liang Y. Interaction of cellulase with sodium dodecyl sulfate at critical micelle concentration level. Colloids Surf B Biointerfaces. 2006; 49:175-180. 